\title{
ANALISIS USAHATANI TANAMAN SELA DI ANTARA KARET DI WILAYAH KOTA PRABUMULIH, SUMATERA SELATAN
}

\author{
Analysis of Rubber Intercropping System \\ in Prabumulih City, South Sumatra Province \\ Dwi Shinta AGUSTINA, Lina Fatayati SYARIFA, Cicilia NANCY, dan M.J. ROSYID \\ Balai Penelitian Sembawa, Pusat Penelitian Karet \\ Jalan Raya Palembang - P. Balai KM 29, PO. BOX 1127 \\ Palembang, Sumatera Selatan 30001 \\ Email : dwishinta_sbw@yahoo.com
}

Diterima : 9 Februari 2015 / Direvisi : 20 Mei 2015 / Disetujui : 15 Juli 2015

\begin{abstract}
One alternative effort in order to increase the income of smallholders was by practicing rubber based mix-cropping with other supporting plants. Rubber based intercropping system had been established by smallholders in South Sumatra for many years. One village in South Sumatra which practices rubber intercropping system is Pangkul Village in Prabumulih District. This research was conducted to get the description of rubber based intercropping system practiced in Pangkul Village and the income getting from this cultivation system. The data collection was conducted by discussing with the farmers' group that had 23 members, and it was assisted by the village staff and field extension worker. Smallholders in Pangkul Village were the project farmers who already had the high interest and motivation to adopt the recommended technologies. This could be seen from the high yield of rubber and input given to rubber plant has already met the recommendation. Smallholders planted the intercrop between rubber trees, such as the vegetables which could be harvested within a short time so that could be done intensively, as well as rubber planting material. The average income from this farming system practice was Rp 7 million per month. Baby tomato was the main plant which gave the highest contribution to the total income (67\% from the total farming income).
\end{abstract}

Keywords: Hevea brasiliensis, smallholders, intercrops, income

\section{Abstrak}

Salah satu alternatif untuk meningkatkan pendapatan petani karet adalah adanya komoditas pendukung yang diusahakan secara mix-cropping dengan tanaman karet. Pola usahatani berbasis karet telah diusahakan petani di Sumatera Selatan selama bertahun-tahun. Salah satu lokasi di Provinsi Sumatera Selatan yang mengusahakan tanaman sela sebagai sumber pendapatan tambahan adalah Desa
Pangkul di Kota Prabumulih. Penelitian ini bertujuan menampilkan gambaran mengenai usahatani karet dengan tanaman sela dan pendapatan yang diperoleh dari pengusahaan pola usahatani ini. Metode yang digunakan dalam pengambilan data melalui diskusi langsung dengan kelompok tani yang beranggotakan 23 orang dengan didampingi oleh perangkat desa dan petugas Penyuluh Pertanian Lapangan (PPL). Hasil penelitian menunjukkan bahwa petani di Desa Pangkul pada umumnya telah mempunyai minat dan motivasi yang kuat untuk menerapkan teknologi anjuran. Hal ini terlihat dari produksi tanaman karet yang cukup tinggi serta input yang diberikan pada tanaman karet dan tanaman sela sudah sesuai dengan anjuran. Tanaman sela yang umum diusahakan petani meliputi tanaman sayur-sayuran dan bibit karet. Tanaman sayursayuran dapat dipanen dalam waktu singkat sehingga pengusahaannya dapat dilakukan secara intensif. Pada umumnya tanaman sela diusahakan selama tiga tahun masa tanaman belum menghasilkan (TBM). Rata-rata pendapatan usahatani dari tanaman sela adalah Rp 7 juta per bulan. Pendapatan yang diperoleh dari tanaman sela cukup tinggi terutama dari tanaman tomat kecil yaitu sekitar $67 \%$ dari total pendapatan usahatani.

Kata kunci: Hevea brasiliensis, karet rakyat, tanaman sela, pendapatan

\section{PENDAHULUAN}

Karet alam merupakan komoditas unggulan di Provinsi Sumatera Selatan, karena merupakan sumber devisa utama dari sub sektor perkebunan dan sumber pendapatan utama bagi jutaan penduduk. Luas areal karet di Provinsi Sumatera Selatan pada tahun 2011 mencapai 1,2 juta ha dengan produksi mencapai 1,05 juta ton. Luasan tersebut didominasi oleh 
perkebunan rakyat yaitu mencapai 94\% yang sebagian besar merupakan areal karet swadaya. Produksi karet Sumatera Selatan selama 26 tahun terakhir menunjukkan laju pertumbuhan yang sangat pesat. Apabila pada tahun 1982 ekspor karet Sumsel baru sekitar 120 ribu ton, pada tahun 2012 telah mencapai 903 ribu ton (Gapkindo, 2013).

Pada tahun 2006, produktivitas karet di Provinsi Sumatera Selatan hanya mencapai $980 \mathrm{~kg} / \mathrm{ha}$ (Ditjenbun, 2007). Namun, rata-rata produktivitas karet Sumatera Selatan pada tahun 2011 sudah mencapai $1440 \mathrm{~kg} / \mathrm{ha} /$ tahun (Dinas Perkebunan Sumatera Selatan, 2011). Hal ini merupakan hasil dari berbagai upaya yang dilakukan oleh pemerintah melalui proyek-proyek berbantuan, kemitraan dengan instansi-instansi terkait maupun swadaya petani sendiri. Sumatera Selatan sebagai salah satu produsen karet alam terbesar terus melakukan langkah-langkah strategis untuk meningkatkan produksi dan produktivitasnya melalui gerakan peremajaan karet tua seluas 100 ribu ha, dan juga pengembangan karet seluas 80 ribu ha sampai tahun 2009. Pada akhir 2009 diharapkan luas areal perkebunan karet Sumatera Selatan akan mencapai 1 juta ha dengan total produksi sekitar 800 ribu ton karet kering atau sekitar 30\% dari produksi karet nasional (Nancy dan Supriyanto, 2008).

Pemerintah telah melakukan berbagai strategi untuk memajukan pembangunan karet rakyat diantaranya melalui proyek pengembangan karet rakyat. Dari total areal karet rakyat di Provinsi Sumatera Selatan, yang baru ditangani proyek adalah $8 \%$ dari total areal atau sekitar 77 ribu ha, yaitu PIR (17 325 ha), TCSDP (55 ribu ha) dan P2WK ( 5 ribu ha), selebihnya adalah swadaya petani (92\%) (Dinas Perkebunan Provinsi Sumatera Selatan, 2006).

Berbagai proyek pengembangan karet telah dapat memperbaiki kondisi perkebunan karet di beberapa wilayah Sumatera Selatan, meningkatkan produktivitas kebun, dan pendapatan petani peserta proyek. Secara tidak langsung keberadaan proyek telah meningkatkan kegiatan ekonomi wilayah pengembangan, meningkatkan pengetahuan dan motivasi petani karet sekitar proyek, dan menumbuhkan kelembagaan agribisnis karet seperti pemasaran bokar dan penangkaran benih karet (Supriadi et al., 2006).

Menurut Blencowe (1989) dalam Rosyid et al. (1992), peningkatan produktivitas lahan dan pendapatan petani karet di wilayah Asia Tenggara dapat diupayakan melalui pengusahaan tanaman sela baik pada saat tanaman masih muda maupun setelah menghasilkan. Salah satu alternatif untuk meningkatkan pendapatan petani adalah melalui pengelolaan komoditas pendukung secara mix-cropping dengan tanaman karet. Jenis tanaman sela yang diusahakan petani antar wilayah sangat bervariasi, karena dipengaruhi oleh faktor teknis (tanah, iklim), pasar, dan kebiasaan petani.

Kondisi harga karet yang membaik pada tahun 2004 sampai tahun 2013 telah merubah kecenderungan petani yang semula menanam tanaman sela menjadi tidak lagi mengusahakannya. Salah satu lokasi yang sampai saat ini masih mengusahakan tanaman sela terdapat di Desa Pangkul, Kota Prabumulih, Provinsi Sumatera Selatan. Di Desa Pangkul telah tercipta suatu pola budaya menanam tanaman sela hingga saat ini. Hal ini disebabkan telah ada suatu pola pemasaran tanaman sela yang persisten dimana pembeli (konsumen) mendatangi petani yang menanam tanaman sela secara rutin sejak dahulu. Tulisan ini bertujuan untuk memberikan gambaran usahatani tanaman sela di antara karet yang dilakukan oleh petani dan jumlah pendapatan yang diperoleh.

\section{BAHAN DAN METODE}

Penelitian dilaksanakan pada tahun 2013 di Desa Pangkul, Kota Prabumulih, Provinsi Sumatera Selatan. Pendekatan penelitian dilakukan dengan melihat karakteristik usahatani karet yang dilakukan oleh petani setempat. Data yang dikumpulkan meliputi data primer dan data sekunder. Data primer diperoleh melalui diskusi langsung dengan melibatkan kelompok tani yang ada di desa Pangkul. Jumlah peserta diskusi sebanyak 23 orang, didampingi oleh perangkat desa dan petugas Penyuluh Pertanian Lapangan (PPL) dari 
Dinas Perkebunan. Diskusi dilaksanakan dengan menggunakan daftar pertanyaan yang telah dipersiapkan sebelumnya. Sedangkan data sekunder diperoleh dari berbagai sumber informasi. Beberapa informasi yang relevan dengan penelitian ini diperoleh dari jurnal, laporan dan penelitian terdahulu yang berkaitan.

Data yang dikumpulkan ditabulasi dan dianalisa secara deskriptif. Pola usahatani karet berbasis tanaman sela dihitung dengan menggunakan formula sebagai berikut (Soekartawi, 1995):

$$
\begin{aligned}
& \mathrm{I}=\mathrm{TP}-\mathrm{TB} \ldots \ldots \ldots \ldots \\
& \mathrm{I}=(\mathrm{Q} . \mathrm{Pq})-\mathrm{TB} .
\end{aligned}
$$

dimana:

I $\quad=$ Pendapatan $(\mathrm{Rp})$

$\mathrm{TP}=$ Total Penerimaan $(\mathrm{Rp})$

$\mathrm{TB}=$ Total Biaya $(\mathrm{Rp})$

$\mathrm{Pq} \quad=$ Harga per unit produksi $(\mathrm{Rp} / \mathrm{kg})$

$\mathrm{Q} \quad=$ Produksi $(\mathrm{kg})$

Pembahasan dalam tulisan ini meliputi:

1. Pola usahatani karet berbasis tanaman sela yang dipraktekkan oleh petani selama tiga tahun masa tanaman belum menghasilkan (TBM).

2. Biaya produksi (input) pada setiap pola usahatani ( $\mathrm{Rp})$

3. Produksi atau output ( $\mathrm{kg} /$ tahun) dan harga jual (Rp) pada setiap pola usaha

\section{HASIL DAN PEMBAHASAN}

\section{Kondisi Umum Usahatani Karet Berbasis Tanaman Sela}

Di Desa Pangkul sebagian besar petani merupakan petani maju karena di desa Pangkul pernah dikembangkan Proyek Pengembangan Karet Rakyat (PPKR). Yang dimaksud dengan petani maju adalah petani yang telah mempunyai minat dan motivasi yang kuat untuk menerapkan teknologi anjuran. Pendekatan penyuluhan umum dan masal tidak lagi diperlukan, karena petani telah berada pada tahap penerapan teknologi. Pendekatan penyuluhan yang dibutuhkan adalah pendampingan dengan materi penyuluhan yang spesifik yang disesuaikan dengan kebutuhan petani atau untuk mengatasi suatu masalah (Supriadi dan Nancy, 2005).
Di Desa Pangkul terdapat beberapa pola petani yang mengusahakan tanaman sela yaitu 1) petani yang mengusahakan tanaman sela dengan sistem sewa di kebun karet milik orang lain, 2) petani pemilik mengizinkan petani lain untuk mengusahakan tanaman sela di tanah miliknya dengan sistem bagi hasil, 3) petani pemilik tanah mengusahakan sendiri tanaman sela, dan 4) petani menumpang mengusahakan tanaman sela, tanpa sewa dan tanpa bagi hasil (semua hasil untuk petani) namun harus memelihara kebun karet milik petani pemilik tanah. Sebagian besar petani di Desa Pangkul sudah menanam bibit karet unggul, bahkan sebagian besar sudah mampu menghasilkan bibit karet unggul sendiri. Pada tiga tahun pertama masa tanaman karet belum menghasilkan (TBM), tanaman sela yang diusahakan adalah tanaman sela yang berorientasi pasar seperti sayur-sayuran dan bibit karet.

Pola usahatani karet yang dilakukan oleh sebagian besar petani di Desa Pangkul adalah budidaya karet berbasis tanaman sela. Pemilihan tanaman sela yang akan diusahakan dan tingkat pengelolaannya tidak hanya berdasarkan faktor teknis agronomis tetapi juga dipengaruhi oleh aspek sosial ekonomi petani, di antaranya faktor kebiasaan, tujuan serta ketersediaan pasar (input maupun output) untuk usahataninya. Pola tanaman sela karet di Desa Pangkul selama tiga tahun masa TBM disajikan pada Tabel 1.

Dari Tabel 1 terlihat bahwa jenis tanaman sela yang diusahakan petani selama tiga tahun masa TBM pada umumnya adalah tanaman sela sayursayuran (cabai, tomat kecil, dan terong) dan bibit karet. Pengusahaan tanaman sela sayuran sangat menguntungkan petani karena periode tanam dan panen yang cukup singkat sehingga pengusahaannya dapat dilakukan dalam beberapa periode.

Setelah persiapan lahan, petani menanam cabai pada bulan September sedangkan karet ditanam pada bulan Desember. Cabai dapat dipanen lima bulan setelah tanam (Januari). Selanjutnya, pada bulan Februari petani menanam bibit karet sebagai tanaman sela dan dapat mulai diokulasi pada bulan Oktober. Enam bulan setelah okulasi, petani menanam sayur- 
Tabel 1. Pola tanaman sela karet di Desa Pangkul, Prabumulih Table 1. Rubber intercropping pattern in Pangkul village, Prabumulih

\begin{tabular}{|c|c|c|c|c|c|c|c|c|c|c|c|c|c|c|c|c|c|c|c|c|c|c|c|c|c|c|}
\hline \multirow{2}{*}{$\begin{array}{l}\text { Jenis Tanaman } \\
\text { Intercropping plant }\end{array}$} & \multicolumn{26}{|c|}{$\begin{array}{c}\text { Tahun, Bulan } \\
\text { Year, Month }\end{array}$} \\
\hline & 9 & 10 & 11 & 12 & 1 & 2 & 3 & 4 & 5 & 6 & 7 & 8 & 9 & 10 & 11 & 12 & 1 & 2 & $\begin{array}{|ll|}3 & 4\end{array}$ & 5 & 6 & 7 & \begin{tabular}{|l|}
89 \\
\end{tabular} & 10 & 11 & 12 \\
\hline \multicolumn{27}{|l|}{ Chili } \\
\hline$\square$ Penanaman & $\mathrm{x}$ & & & & & & & & & & & & & & & & & & & & & & & & & \\
\hline \multicolumn{27}{|l|}{$\square$ Planting } \\
\hline \multicolumn{27}{|l|}{$\square$ Maintenance } \\
\hline$\square$ Pemanenan & & & & & $\mathrm{x}$ & & & & & & & & & & & & & & & & & & & & & \\
\hline \multicolumn{27}{|l|}{$\square$ Harvesting } \\
\hline \multicolumn{27}{|l|}{ Bibit Karet } \\
\hline \multicolumn{27}{|l|}{ Rubber Planting } \\
\hline \multicolumn{27}{|l|}{ Material } \\
\hline$\square$ Penanaman & & & & & & $\mathrm{x}$ & & & & & & & & & & & & & & & & & & & & \\
\hline \multicolumn{27}{|l|}{$\square$ Grafting } \\
\hline \multicolumn{27}{|l|}{ Tomat Kecil } \\
\hline \multicolumn{27}{|l|}{ Baby tomato } \\
\hline$\square$ Penanaman & & & & & & & & & & & & & & & & & & & & $x$ & & & & & & \\
\hline$\square$ Planting & & & & & & & & & & & & & & & & & & & & & & & & & & \\
\hline$\square$ Pemeliharaan & & & & & & & & & & & & & & & & & & & & & $\mathrm{x}$ & & & & & \\
\hline$\square$ Maintenance & & & & & & & & & & & & & & & & & & & & & & & & & & \\
\hline$\square$ Pemanenan & & & & & & & & & & & & & & & & & & & & & & $x$ & & & & \\
\hline$\square$ Harvesting & & & & & & & & & & & & & & & & & & & & & & & & & & \\
\hline Terong & & & & & & & & & & & & & & & & & & & & & & & & & & \\
\hline Eggplant & & & & & & & & & & & & & & & & & & & & & & & & & & \\
\hline
\end{tabular}

sayuran lagi seperti tomat kecil dan terong yang dapat dipanen tiga sampai empat bulan setelah tanam.

Berdasarkan hasil penelitian Rosyid (2007) diketahui bahwa tanaman sela tidak berpengaruh negatif terhadap pertumbuhan tanaman karet, bahkan apabila tanaman sela dikelola dengan baik dapat meningkatkan pertumbuhan tanaman karet, dibandingkan dengan tanaman karet yang tidak ada tanaman selanya. Kondisi ini disebabkan oleh: (1) intensitas pengawasan kebun menjadi lebih tinggi; (2) kompetisi tanaman karet dengan tanaman lain menjadi terbatas, karena dengan adanya tanaman sela pertumbuhan gulma dapat dikendalikan, disamping itu tanaman sela juga diberi input pupuk yang juga akan diserap tanaman karet, dan (3) kondisi tanah menjadi lebih gembur, karena ada pengolahan tanah untuk tanaman sela.

\section{Analisis Usahatani Tanaman Sela}

Pada dasarnya usahatani keluarga merupakan suatu unit perusahaan yang terdiri atas berbagai cabang usaha dan memiliki keterbatasan berbagai sumberdaya terutama modal dan tenaga kerja. Pendapatan petani merupakan ukuran penghasilan yang diterima petani dari usahataninya (Suharyanto et al., 2004). Penerimaan, biaya produksi (input usahatani), dan pendapatan usahatani berbasis karet di Desa Pangkul ditampilkan pada Tabel 2.

Data pada Tabel 2 menunjukkan bahwa tanaman sela tomat kecil memberikan kontribusi pendapatan terbesar yaitu $67 \%$ dari total pendapatan usahatani, diikuti cabai, terong, dan bibit karet yang masing-masing memberikan kontribusi sebesar $20 \%, 11 \%$, dan $2 \%$ dari total pendapatan usahatani. Pendapatan 
Tabel 2. Analisis input - output per ha tanaman sela karet selama 3 tahun di Desa Pangkul, Kota Prabumulih, 2013

Table 2. Analysis of input - output per ha of intercrop during 3 years in Pangkul Village, Prabumulih, 2013

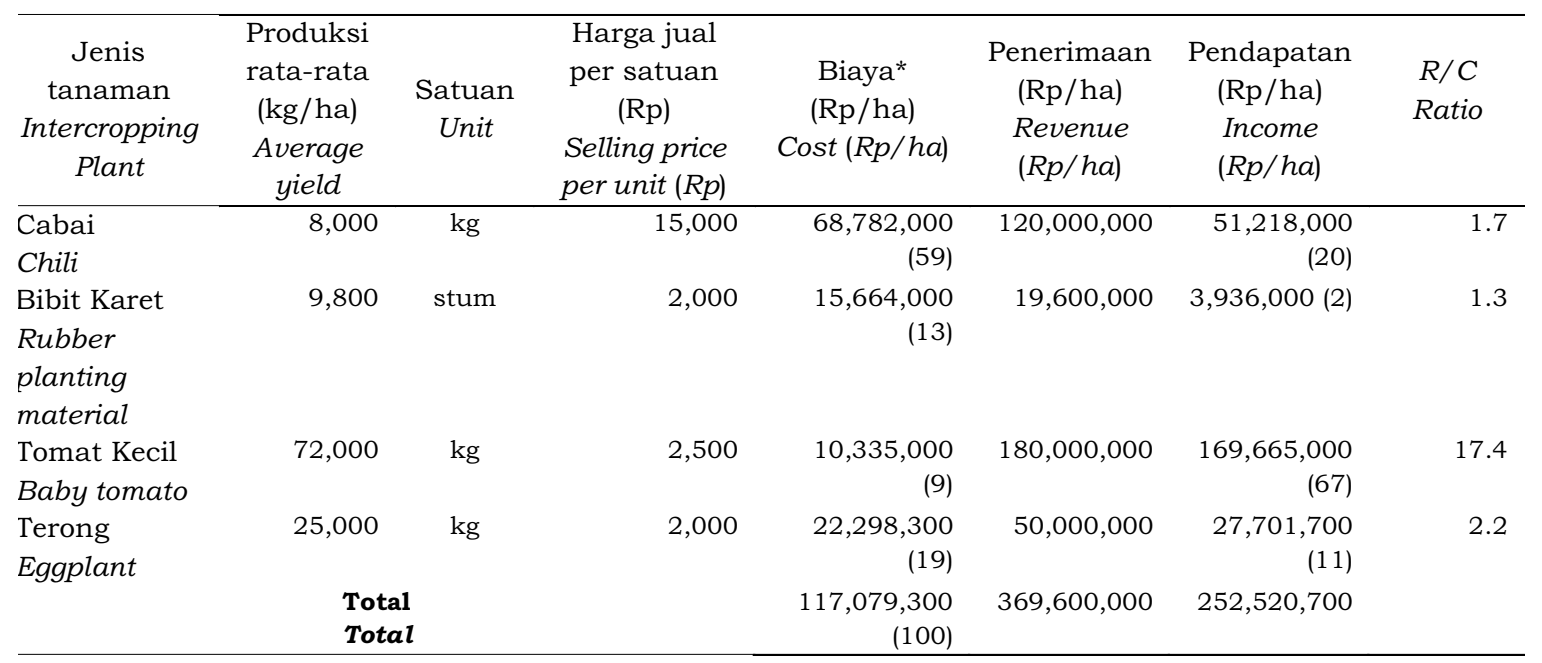

Keterangan (note): *tenaga kerja keluarga dan gotong royong tidak diperhitungkan sebagai biaya (family laborwas not counted as a cost)

Angka dalam kurung merupakan persentase terhadap total (number in parenthesis is the percentage to the total)

dari tanaman sela ini hanya diperoleh petani sampai tahun ketiga masa TBM karet. Dilihat dari nilai $\mathrm{R} / \mathrm{C}$ ratio, seluruh jenis tanaman sela yang diusahakan memiliki $\mathrm{R} / \mathrm{C}$ ratio lebih dari satu sehingga secara ekonomis layak untuk diusahakan.

Secara keseluruhan, total pendapatan rata-rata yang diterima dari tanaman sela dalam kurun waktu 3 tahun mencapai Rp 252 juta. Dengan demikian, rata-rata pendapatan yang diterima petani setiap bulan sebesar Rp 7 juta. Ditinjau dari kelayakan untuk memenuhi standar upah minimum regional Provinsi Sumatera Selatan, pendapatan total usahatani karet dengan tanaman sela sudah melampaui upah minimum regional Provinsi Sumatera Selatan pada tahun 2013 sebesar Rp 1,630,000 per bulan (Depnakertrans, 2014). Dengan demikian pengusahaan tanaman sela di antara tanaman karet layak dari sisi pendapatan.

Pendapatan yang ditampilkan pada tulisan ini merupakan harga yang berlaku pada saat penelitian yaitu pada kondisi harga tanaman sela normal. Pendapatan yang diterima petani sangat tergantung pada tingkat harga. Pada kondisi harga palawija sedang turun, maka pendapatan yang diperoleh akan menurun dan sebaliknya jika harga palawija sedang mencapai titik tertinggi maka pendapatan yang diperoleh menjadi lebih besar.

Ditinjau dari biaya yang dikeluarkan, tanaman cabai menyerap biaya produksi terbesar yaitu $59 \%$ dari total biaya usahatani, diikuti oleh terong, bibit karet, dan tomat kecil yang masing-masing menyerap biaya sebesar 19\%, 13\%, dan 9\% dari total biaya usahatani. Biaya yang diperhitungkan adalah biaya tenaga kerja upahan pada kegiatan-kegiatan tertentu seperti pada kegiatan penanaman, pemupukan, penyiangan, pemanenan, dan lain-lain. Sedangkan kegiatan yang dilakukan secara bergotong royong seperti pembukaan lahan tidak diperhitungkan sebagai biaya. Demikian juga halnya dengan kegiatan yang dilakukan oleh tenaga kerja keluarga seperti kegiatan mencangkul tidak diperhitungkan sebagai biaya. Biaya untuk tanaman sela sudah termasuk biaya untuk pemeliharaan tanaman karet karena selama masih ada tanaman sela, tanaman karet ikut terpelihara dengan baik. Grafik penerimaan dan biaya pada masing-masing tanaman dapat dilihat pada Gambar 1. 


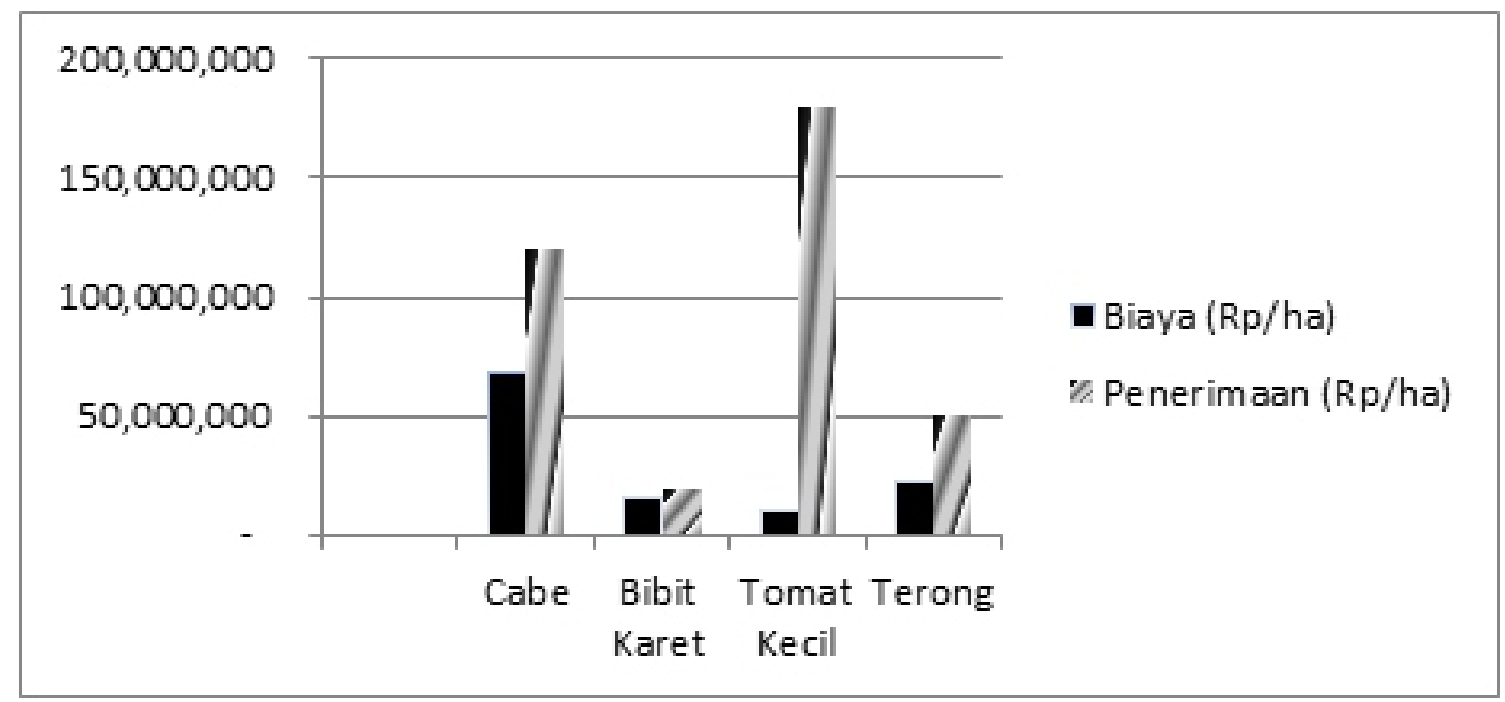

Gambar 1. Grafik penerimaan dan biaya usahatani tanaman sela karet di Desa Pangkul, Prabumulih

Figure 1. Graph of revenue and cost of rubberintercrop in Pangkul Village, Prabumulih

Dari Tabel 2 terlihat bahwa pengusahaan tanaman sela di antara tanaman karet memberikan keuntungan bagi petani. Hal ini dapat terlihat dari nilai $\mathrm{R} / \mathrm{C}$ Ratio (nilai perbandingan antara penerimaan dan biaya) yang lebih dari 1 pada semua jenis tanaman. Nilai $\mathrm{R} / \mathrm{C}$ ratio terbesar dihasilkan dari pengusahaan tanaman tomat kecil yaitu 17.4, diikuti oleh terong, cabe, dan bibit karet yang masingmasing memiliki $\mathrm{R} / \mathrm{C}$ ratio sebesar $2.2 ; 1.7$; dan 1.3.

Tanaman cabai menyerap biaya terbesar dibandingkan tanaman lainnya. Besarnya biaya yang dibutuhkan tanaman cabai karena petani memberikan input sesuai dengan anjuran budidaya tanaman cabai. Perincian biaya budidaya tanaman cabai di Desa Pangkul disajikan pada Lampiran 1.

Dari Lampiran 1 terlihat bahwa komponen biaya usahatani cabai yang terbesar adalah biaya tenaga kerja untuk panen, penyemprotan, dan pemupukan yaitu masing-masing Rp 16 juta, Rp 13 juta, dan 12 juta. Hal ini disebabkan pemupukan dan penyemprotan dilakukan secara intensif untuk memperoleh hasil panen yang optimal.

Biaya produksi tanaman terong juga termasuk tinggi, kedua terbesar setelah tanaman cabai yaitu mencapai Rp 29 juta.
Seperti halnya tanaman cabe, komponen biaya terbesar pada usahatani tanaman sela terong adalah biaya tenaga kerja untuk pemupukan, panen, dan penyemprotan yaitu masing-masing Rp 7 juta, Rp 5 juta, dan Rp 4 juta. Perincian biaya produksi tanaman sela terong disajikan pada Lampiran 2.

Usahatani tanaman sela bibit karet membutuhkan komponen biaya terbesar ketiga setelah tanaman sela cabai dan terong yaitu meliputi 13\% dari total biaya usahatani. Perincian biaya usahatani tanaman sela bibit karet disajikan pada Lampiran 3. Dari data yang ditampilkan pada Lampiran 3 terlihat bahwa biaya produksi terbesar untuk tanaman sela bibit karet adalah pada kegiatan okulasi dan penanaman yaitu masing-masing Rp 8 juta dan Rp 4 juta.

Tanaman tomat kecil merupakan tanaman sela dengan biaya produksi terkecil dibandingkan tanaman sela lainnya yaitu hanya sekitar Rp 10 juta. Komponen biaya produksi terbesar adalah pada biaya pemupukan dan panen masing-masing sebesar Rp 4 juta (41\% terhadap total biaya) dan Rp 3 juta (29\% terhadap total biaya). Selanjutnya biaya pembersihan setelah panen sebesar Rp 2 juta (19\% terhadap total biaya), kemudian biaya penyemprotan sebesar Rp 700 ribu (7\% terhadap total biaya), dan terakhir biaya penanaman yang 
hanya mencakup Rp 400 ribu (4\% terhadap total biaya). Perincian biaya produksi tanaman sela tomat kecil disajikan pada Lampiran 4.

\section{KESIMPULAN DAN SARAN}

Petani di Desa Pangkul mengusahakan tanaman sela berupa tanaman sayuran (palawija) selama 3 tahun tanaman karet belum menghasilkan. Pengusahaan tanaman karet berbasis tanaman sela memberikan keuntungan bagi petani. Ratarata pendapatan yang diperoleh dari tanaman sela selama kurun waktu 3 tahun sebesar Rp 7 juta per bulan. Dari hasil penelitian ini dapat disarankan agar pengusahaan tanaman sela terus digalakkan karena dapat memberikan tambahan pendapatan terutama selama masa TBM. Tanaman sela palawija yang dapat menghasilkan dalam waktu cepat dapat dijadikan sebagai alternatif tanaman sela yang sangat baik bagi petani.

\section{DAFTAR PUSTAKA}

Dinas Perkebunan Provinsi Sumatera Selatan. 2011. Statistik Perkebunan Provinsi Sumatera Selatan. Dinas Perkebunan Provinsi Sumatera Selatan, Palembang.

Dinas Perkebunan Provinsi Sumatera Selatan. 2006. Profil Agribisnis dan Agroindustri Karet Provinsi Sumatera Selatan. Dinas Perkebunan Provinsi Sumatera Selatan, Palembang.

Gabungan Perusahaan Karet Indonesia. 2013. List of Members. GAPKINDO, Jakarta.

Departemen Tenaga Kerja dan Transmigrasi. 2014. Surat keputusan Gubernur Sumatera Selatan tentang Perubahan atas Keputusan Gubernur Provinsi Sumatera Selatan tentang Upah Minimum Provinsi Sumatera Selatan Tahun2013. http://jdih.depnaker trans.go.id diakses tanggal 30 Juni 2014.
Nancy, C. dan Supriyanto. 2008. Pengelolaan dan Penyaluran Bahan Tanam Karet di Sumatera Selatan. Prosiding Lokakarya Nasional Agribisnis Karet 2008. Yogyakarta, 20 -21 Agustus.

Rosyid, M. J., G. Wibawa., U. Junaidi., dan A. Gunawan. 1992. Pengujian Diversifikasi Beberapa Tanaman Tahunan di Antara Tanaman Karet. Risalah Seminar Hasil Penelitian Balai Penelitian Sembawa Tahun 1992/1993. Balai Penelitian Sembawa.: 105-125.

Rosyid, M. J. 2007. Pengaruh Tanaman Sela terhadap Pertumbuhan Karet pada Areal Peremajaan Partisipatif di Kabupaten Sarolangun Jambi. Jurnal Penelitian Karet 25(2) : 25-36.

Soekartawi, 1995. Analisis Usahatani. Universitas Indonesia (UI-Press), Jakarta.

Suharyanto, Suprapto dan Rubiyo. 2004. Analisis Pendapatan dan Distribusi Pendapatan Usahatani Tanaman Perkebunan Berbasis Kelapa di Kabupaten Tabanan. Jurnal Pengkajian dan Pengembangan Teknologi Pertanian 7(2) : 146-154.

Supriadi, M., I. Boerhendhy., dan C. Nancy. 2006. Strategi Peremajaan Karet Rakyat di Provinsi Kalimantan Selatan. Gelar Teknologi Kalimantan Selatan. Balai Penelitian Sembawa, Palembang.

Supriadi, M dan C. Nancy. 2005. Model Pengembangan Karet Partisipatif : Konsepsi dan Tantangan Penerapannya. Gelar Teknologi Kalimantan Timur. Balai Penelitian Sembawa, Palembang. 
Lampiran 1. Biaya produksi per ha tanaman sela cabe di Desa Pangkul, Prabumulih, 2013

Appendices 1. Production cost per ha of chili intercrops in Pangkul Village, Prabumulih, 2013

\begin{tabular}{|c|c|c|c|c|c|c|c|c|c|c|c|}
\hline \multirow[b]{2}{*}{$\begin{array}{l}\text { Kegiatan } \\
\text { Activities }\end{array}$} & \multicolumn{4}{|c|}{$\begin{array}{l}\text { Tenaga Kerja } \\
\text { Labor }\end{array}$} & \multicolumn{5}{|c|}{$\begin{array}{l}\text { Bahan } \\
\text { Material }\end{array}$} & \multirow[b]{2}{*}{$\begin{array}{c}\text { Total Biaya } \\
\text { Total costs } \\
(R p)\end{array}$} & \multirow[b]{2}{*}{ Keterangan } \\
\hline & $\begin{array}{l}\text { Unit } \\
\text { Unit }\end{array}$ & $\begin{array}{c}\text { Jml } \\
\text { Amount }\end{array}$ & $\begin{array}{c}\text { Harga } \\
\text { Satuan } \\
\text { Price per } \\
\text { unit } \\
(R p) \\
\end{array}$ & $\begin{array}{l}\text { Biaya } \\
\text { Costs } \\
(R p)\end{array}$ & $\begin{array}{l}\text { Jenis } \\
\text { Types }\end{array}$ & $\begin{array}{l}\text { Unit } \\
\text { Unit }\end{array}$ & $\begin{array}{c}\text { Jml } \\
\text { Amount }\end{array}$ & $\begin{array}{c}\text { Harga } \\
\text { Satuan } \\
\text { Price per } \\
\text { unit } \\
(R p) \\
\end{array}$ & $\begin{array}{l}\text { Biaya } \\
\text { Costs } \\
(R p)\end{array}$ & & \\
\hline $\begin{array}{l}\text { Persiapan lahan } \\
\text { Land Preparation }\end{array}$ & $\begin{array}{c}\text { HOK } \\
\text { Mandays }\end{array}$ & - & & & - & - & - & & - & & Gotong royong \\
\hline Mengaduk dan mengecer & $\begin{array}{l}\text { HOK } \\
\text { Mandaus }\end{array}$ & 19 & 50,000 & 950,000 & Pupuk & $\mathrm{krg}$ & 600 & 9.000 & 5.400 .000 & $9,474,500$ & \\
\hline Stirring + spreading & & & & & TSP & $\mathrm{Kg}$ & 300 & 7.315 & 2.194 .500 & & \\
\hline fertilizer & & & & & $\begin{array}{l}\text { KCL } \\
\text { Dolomit }\end{array}$ & $\begin{array}{l}\mathrm{Kg} \\
\mathrm{Kg}\end{array}$ & $\begin{array}{l}150 \\
50\end{array}$ & $\begin{array}{r}6.200 \\
10.000\end{array}$ & $\begin{array}{l}930.000 \\
500.000\end{array}$ & & \\
\hline $\begin{array}{l}\text { Menanam } \\
\text { Planting }\end{array}$ & $\begin{array}{l}\mathrm{HOK} \\
\text { Mandays }\end{array}$ & 30 & 50,000 & $1,500,000$ & - & - & - & & - & $1,500,000$ & \\
\hline $\begin{array}{l}\text { Pemupukan } \\
\text { Manuring }\end{array}$ & $\begin{array}{c}\mathrm{HOK} \\
\text { Mandays }\end{array}$ & 10 & 50,000 & 500,000 & NPK & $\mathrm{kg}$ & 200 & 8.600 & 1.720 .000 & $2,220,000$ & \\
\hline Pemupukan melingkar & HOK & 10 & 50,000 & 500,000 & & & & 8.600 & & $10,460,000$ & \\
\hline Circular manuring & Mandays & & & & NPK & $\mathrm{kg}$ & 300 & & 2.580 .000 & & \\
\hline & & & & & Urea & $\mathrm{kg}$ & 600 & 5.400 & 3.240 .000 & & \\
\hline & & & & & $\mathrm{SP}$ & $\mathrm{kg}$ & 400 & 5.700 & 2.280 .000 & & \\
\hline & & & & & $\mathrm{KCl}$ & $\mathrm{kg}$ & 300 & 6.200 & 1.860 .000 & & \\
\hline Menyiram & HOK & 120 & 50,000 & $6,000,000$ & & & & - & - & $6,000,000$ & \\
\hline $\begin{array}{l}\text { Watering } \\
\text { Pendangiran }\end{array}$ & $\begin{array}{r}\text { Mandays } \\
\text { HOK }\end{array}$ & 30 & 50,000 & $1,500,000$ & - & - & - & & - & $1,500,000$ & \\
\hline Soil friabling & Mandays & & & & - & - & - & & & & \\
\hline Membumbun I & HOK & 60 & 50,000 & $3,000,000$ & & & & - & - & $3,000,000$ & \\
\hline Pile up the soil I & Mandays & & & & & - & - & & & & \\
\hline Membumbun II & & 40 & 50,000 & $2,000,000$ & & & & - & - & $2,000,000$ & \\
\hline Pile up the soil II & Mandays & & & & - & - & - & & & & \\
\hline Penyemprotan I & & 12 & 50,000 & 600,000 & & & & 250.000 & & $1,057,500$ & \\
\hline Spraying I & Mandays & & & & Curacron & 1 & 1 & & 250.000 & & \\
\hline & & & & & Antracol & $\mathrm{kg}$ & 1 & 95.000 & 95.000 & & \\
\hline & & & & & Gandazil D & $\mathrm{kg}$ & 1 & 50.000 & 50.000 & & \\
\hline & & & & & Atonic & 1 & 0,5 & 125.000 & 62.500 & & \\
\hline $\begin{array}{l}\text { Penyemprotan II } \\
\text { Snquipi }\end{array}$ & HOK & 32 & 50,000 & $1,600,000$ & & & & 250.000 & & $2,515,000$ & \\
\hline Spraying II & Mandays & & & & Curacron & 1 & 2 & & 500.000 & & \\
\hline & & & & & Antracol & $\mathrm{kg}$ & & 95.000 & 190.000 & & \\
\hline & & & & & Gandazil B & $\mathrm{kg}$ & 2 & $\begin{array}{r}50.000 \\
\end{array}$ & 100.000 & & \\
\hline Penyemprotan III & HOK & 40 & 50,000 & $2,000,000$ & Atonic & & & $\begin{array}{l}1250.000 \\
250.000\end{array}$ & 125.000 & $3,185,000$ & \\
\hline Spraying III & Mandays & & & & Curacron & 1 & 3 & & 750.000 & & \\
\hline & & & & & Antracol & $\mathrm{kg}$ & 3 & 95.000 & 285.000 & & \\
\hline & & & & & Gandazil B & $\mathrm{kg}$ & 3 & 50.000 & 150.000 & & \\
\hline Penyemprotan IV & HOK & 40 & 50,000 & $2,000,000$ & & & & 250.000 & & $3,185,000$ & \\
\hline Spraying IV & Mandays & & & & Curacron & 1 & 3 & & 750.000 & & \\
\hline & & & & & Antracol & $\mathrm{kg}$ & 3 & 95.000 & 285.000 & & \\
\hline Penvemprotan $\mathrm{V}$ & НОК & 40 & 50000 & 2000000 & Gandazil B & $\mathrm{kg}$ & 3 & $\begin{array}{r}50.000 \\
50\end{array}$ & 150.000 & 3185000 & \\
\hline $\begin{array}{l}\text { Spraying V } \\
\text { S }\end{array}$ & Mandays & 40 & & & Curacron & 1 & 3 & 250.000 & 750.000 & $3,185,000$ & \\
\hline & & & & & Antracol & $\mathrm{kg}$ & 3 & 95.000 & 285.000 & & \\
\hline & & & & & Gandazil B & $\mathrm{kg}$ & 3 & 50.000 & 150.000 & & \\
\hline Penyiangan & HOK & 20 & 50,000 & $1,000,000$ & & & & - & - & $1,000,000$ & \\
\hline Weeding & Mandays & & & & - & - & - & & & & \\
\hline Panen & HOK & 320 & 50,000 & $16,000,000$ & & & & - & - & $16,000,000$ & \\
\hline Harvesting & Mandays & & & & - & - & - & & & & \\
\hline Pencabutan & HOK & 50 & 50,000 & $2,500,000$ & & & & - & - & $2,500,000$ & \\
\hline
\end{tabular}


Lampiran 2. Biaya produksi per ha tanaman sela terong di Desa Pangkul, Prabumulih, 2013

Appendices 2. Production cost per ha of eggplant intercrops in Pangkul, Prabumulih, 2013

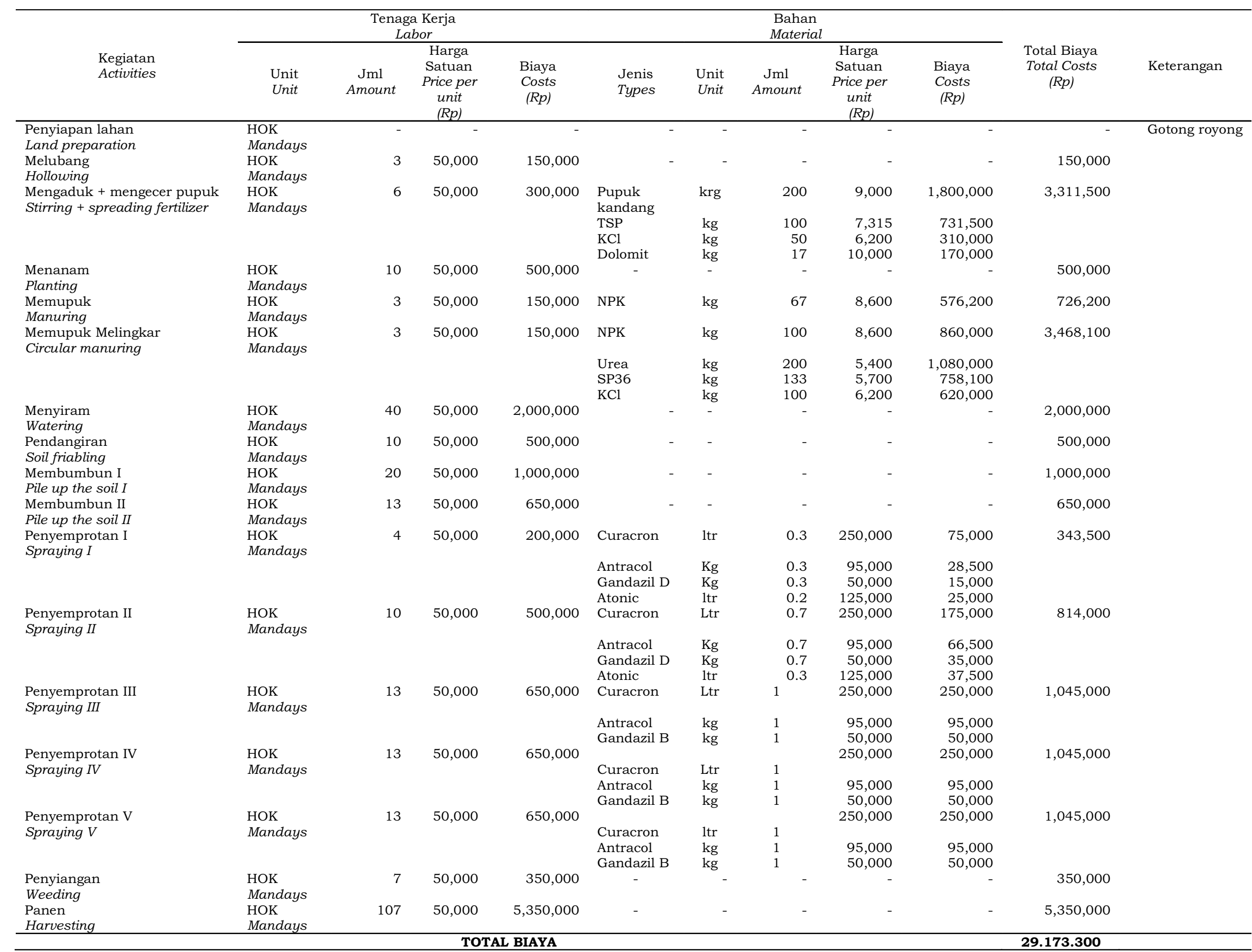


Lampiran 3. Biaya produksi per ha tanaman sela bibit karet di Desa Pangkul, Prabumulih, 2013

Appendices 3. Production cost per ha of rubber planting material intercrops in Pangkul Village, Prabumulih, 2013

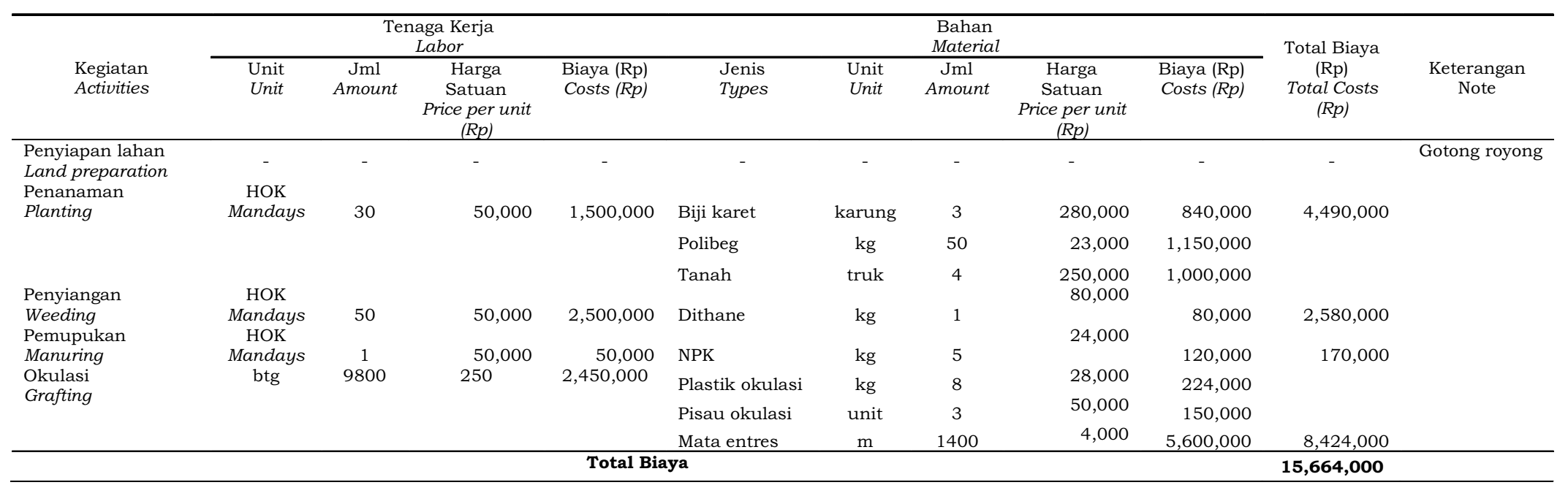

Lampiran 4. Biaya produksi per ha tanaman sela tomat kecil di Desa Pangkul, Prabumulih, 2013

Appendices 4. Production cost per ha of baby tomato intercrops in Pangkul Village, Prabumulih, 2013

\begin{tabular}{|c|c|c|c|c|c|c|c|c|c|c|c|}
\hline \multirow[t]{2}{*}{$\begin{array}{l}\text { Kegiatan } \\
\text { Activities }\end{array}$} & \multicolumn{4}{|c|}{$\begin{array}{c}\text { Tenaga Kerja } \\
\text { Labor }\end{array}$} & \multicolumn{5}{|c|}{$\begin{array}{l}\text { Bahan } \\
\text { Material } \\
\end{array}$} & \multirow{2}{*}{$\begin{array}{l}\text { Total Biaya } \\
\text { (Rp/ha) } \\
\text { Total Costs } \\
\text { (Rp/ha) }\end{array}$} & \multirow[b]{2}{*}{$\begin{array}{l}\text { Keterangan } \\
\text { Note }\end{array}$} \\
\hline & $\begin{array}{l}\text { Unit } \\
\text { Unit }\end{array}$ & $\begin{array}{c}\text { Jml } \\
\text { Amount }\end{array}$ & $\begin{array}{l}\text { Harga } \\
\text { Satuan } \\
\text { (Rp) } \\
\text { Price per } \\
\text { unit (Rp) } \\
\end{array}$ & $\begin{array}{l}\text { Biaya (Rp) } \\
\text { Costs }(R p)\end{array}$ & $\begin{array}{l}\text { Jenis } \\
\text { Types }\end{array}$ & $\begin{array}{l}\text { Unit } \\
\text { Unit }\end{array}$ & $\begin{array}{c}\text { Jml } \\
\text { Amount }\end{array}$ & $\begin{array}{l}\text { Harga } \\
\text { Satuan } \\
\text { (Rp) } \\
\text { Price per } \\
\text { unit (Rp) } \\
\end{array}$ & $\begin{array}{l}\text { Biaya }(\mathrm{Rp}) \\
\text { Costs }(R p)\end{array}$ & & \\
\hline \multirow{2}{*}{$\begin{array}{l}\text { Penyiapan lahan } \\
\text { Land preparation } \\
\text { Penanaman } \\
\text { Planting }\end{array}$} & - & - & - & - & - & - & - & - & - & - & \multirow[t]{14}{*}{ Gotong royong } \\
\hline & HOK & 8 & 50,000 & 400,000 & - & - & - & & - & 400,000 & \\
\hline $\begin{array}{l}\text { Memupuk NPK } \\
\text { Manuring of NPK }\end{array}$ & $\begin{array}{c}\text { HOK } \\
\text { Mandays }\end{array}$ & 16 & 50,000 & 800,000 & NPK & $\mathrm{kg}$ & 400 & 8,600 & $3,440,000$ & $4,240,000$ & \\
\hline \multirow{4}{*}{$\begin{array}{l}\text { Penyemprotan I } \\
\text { Spraying I }\end{array}$} & $\begin{array}{c}\mathrm{HOK} \\
\text { Mandaus }\end{array}$ & - & - & - & Curacron & $1 \mathrm{tr}$ & 0.5 & \multirow[b]{2}{*}{80,000} & 125,000 & \multirow{3}{*}{252,500} & \\
\hline & & & & & Dithane & $\mathrm{kg}$ & 0,5 & & 40,000 & & \\
\hline & & & & & Gandazil D & $\mathrm{kg}$ & 0,5 & 50,000 & 25,000 & & \\
\hline & & & & & Atonic & $1 \mathrm{tr}$ & 0,5 & 125,000 & 62,500 & \multirow{5}{*}{442,500} & \\
\hline \multirow{4}{*}{$\begin{array}{l}\text { Penyemprotan II } \\
\text { Spraying II }\end{array}$} & $\begin{array}{c}\text { HOK } \\
\text { Mandays }\end{array}$ & - & & - & Curacron & $1 \mathrm{tr}$ & 1 & \multirow{2}{*}{80,000} & 250,000 & & \\
\hline & & & & & Dithane & $\mathrm{kg}$ & 1 & & 80,000 & & \\
\hline & & & & & Gandazil B & $\mathrm{kg}$ & 1 & 50,000 & 50,000 & & \\
\hline & & & & & Atonic & ltr & 0,5 & 125,000 & 62,500 & & \\
\hline \multirow{3}{*}{$\begin{array}{l}\text { Panen } \\
\text { Harvesting } \\
\text { Pembersihan } \\
\text { Clearing } \\
\end{array}$} & $\begin{array}{c}\mathrm{HOK} \\
\text { Mandaus }\end{array}$ & & \multirow{3}{*}{$\begin{array}{l}50,000 \\
50,000\end{array}$} & & & & & \multirow{3}{*}{ - } & & \multirow[b]{2}{*}{$3,000,000$} & \\
\hline & $\begin{array}{l}\text { Mandays } \\
\text { HOK }\end{array}$ & 60 & & $3,000,000$ & - & - & - & & - & & \\
\hline & Mandays & 40 & & $2,000,000$ & - & - & - & & - & $2,000,000$ & \\
\hline
\end{tabular}

